\title{
Reports on cestode genus Senga (Dollfus, 1934) (Ptychobothridae, Luhe, 1902) of Mastacembelus armatus from Marathwada region Maharashtra, India
}

\author{
Dhanraj Balbhim Bhure ${ }^{1}$, Sanjay Shamrao Nanware ${ }^{1} \bowtie$ and C.R.Kasar $^{2}$ \\ Received:26.09.2013 \\ Revised:22.01.2014 \\ Accepted:19.02.2014
}

\begin{abstract}
The present investigation deals with biosystematic studies of Pseudophyllidean tapeworm Senga i.e. S. satarensis, S. madhavae, S. mangalbai and S.microrostellata collected from intestine of a Mastacembelus armatus at various places of Marathwada Region (M.S.) India during the period of May, 2012 to Oct., 2013. The worm of present study come closer to all known species of this genus in general topography of organ but differs due to morphometeric measurements and morphological characteristics. The Senga satarensis (Bhure et.al., 2011) comes closer to known species of the genus Senga Dollfus, 1934 in general topography of organ but differs due to taxonomic characters as scolex pear shaped, rostellum bearing 28-30 rostellar hooks, neck absent, testes 175-200 in numbers, cirrus pouch oval, ovary bilobed, vagina runs posteriorly, genital pores oval, vitellaria granular, uterus saccular and egg elongated. The Senga madhavae (Bhure et.al.,2010) comes closer to known species of this genus in general topography of organ but differs due to scolex triangular, rostellum bearing 40-44 rostellar hooks, neck absent, mature proglottids five to six times broader than long, testes 200-220 in numbers, cirrus pouch oval, ovary dumb-bell shaped, genital pores oval in shape, vitellaria granular, uterus saccular and egg elongated. The Senga mangalbai (Bhure et.al.,2011) comes closer to all the known species of this genus in general topography of organ but differs due to scolex conical, hooks 38-42 in numbers, absence of neck, testes 70-80 in numbers, ovary bilobed, each lobe nut shaped and vitellaria granular. The Senga microrostellata (Bhure et.al.,2014) comes closer to all known species of this genus in general topography of organ but differs due to scolex triangular, bothria sessile, rostellum armed with 18-20 hooks which is single circled, absence of neck, mature proglottids 8-9 times broader than long, testes 250-300 in numbers, cirrus pouch elongated, vagina runs posteriorly, ovary dumb-bell shaped, uterus sacular filled with non-operculated eggs and Vitellaria follicular.
\end{abstract}

Keywords: Cestode, Mastacembelus armatus, Marathwada region, Ptychobothridae, Senga

\section{Introduction}

Parasites are extremely abundant and diverse in nature, representing a substantial portion of global biodiversity. Fishes are important components of ecosystem from ecological, medicinal, nutritional and economical point of view. Man uses many fishes as delicious and nutritious food. These fishes are parasitized by helminth parasites, which reduce the food value, as they provide the highly nutritious food. The study of helminth parasites is therefore an urgent necessity today. Because fishes are said to be gold from water, which play an important role in nation's economy of as nutritional point of view, fishes gives high content of proteins, to the deadly growing poor population, which is facing the problems of malnutrition. As a medicinal point of view fishes provides Vitamin-A and Vitamin-D and Author's Address

${ }^{1}$ Research and Post Graduate Department of Zoology, Yeshwant Mahavidyalaya, NANDED

${ }^{2}$ Department of Zoology, S.P.M. Science, Gilani Arts, Commerce College, Ghatanji Dist- YAVATMAL Email-snanware@ rediffmail.com

Copyright by ASEA

All rights of reproduction in any form reserved as a commercial or economical point of view, fishes are useful for preparation of soup, liver oil, skin, other oils etc. Infections are very common in people who are eating poorly cooked or uncooked meat, unhygienic habits and poor sanitation, infection leads to anemia. Parasitic diseases are among the major public health problems of tropical countries including India. Keeping the view in mind the nutritional, economical and medicinal value of fishes the present work is done.Genus Senga was established by Dollfus, (1934) with its type species $S$. besnardi in Betta splendens aquarium at Vincennes, France. Later on cestode species of the genus Senga are added in the genus by Tseng, 1933, Woodland, (1954), Johri, (1956), Fernando and Furtado, (1963), Ramadevi and Rao, (1966), Tadros, (1968), Shinde, (1972), Ramadevi and Rao, (1973), Wardle, Mc Leod and Radinovsky, (1974), Jadhav and Shinde, (1980), Kadam et al., (1981), Majid et al. ,(1984), Jadhav et al., (1991), Tat and Jadhav, (1997), Patil and Jadhav,(2003), Jadhav, (2005), Pande et al, (2006), Bhure et.al., (2007), 
Srivastav et.al., (2007) and Bhure et al., (2010.2011,2014).

\section{Materials and Method}

Cestodes of the genus Senga were collected from the intestine of freshwater fish, Mastacembelus armatus from various places of Marathwada Region (M.S.) India during the period of May, 2012 to Oct., 2013.These cestodes are preserved in hot $4 \%$ formalin and stained with Harris haematoxylin and Borax carmine, passed through various alcoholic grades, cleared in xylene, mounted in D.P.X. and drawings are made with the aid of camera lucida. All measurements are given in millimeters unless otherwise stated. The collected parasites were prepared for identification by standard methods (Schmidt, 1934; Yamaguti, S., 1959; Wardle, et al. 1974; Khalil et al., 1994 and Hiware, et al., 2003)

\section{Results and Discussion}

The present investigation deals with biosystematic studies of Pseudophyllidean cestode parasites of genus Senga viz. S. satarensis, S. madhavae, $S$. mangalbai and S.microrostellata collected from intestine of a Mastacembelus armatus at various places of Marathwada Region (M.S.) India during the period of May, 2012 to Oct., 2013. The worms of present study come closer to all known valid species of this genus in general topography of organ but differ due to morphometrics and morphological characteristics.

\section{Senga sataraensis Bhure et al., 2011:}

Cestodes are long, consisting of scolex, immature, mature and gravid proglottids. Scolex is pear shaped, tapering anteriorly and broad posteriorly and measures $0.635 \mathrm{~mm}$ in length and $0.410 \mathrm{~mm}$ in breadth. Scolex having pair of sessile bothria, which extends from the anterior end to posterior end of the scolex and measures $0.684 \mathrm{~mm}$ in length and $0.067 \mathrm{~mm}$ in breadth. Anterior end of scolex terminates in a rostellum, which is oval to rounded, measures $0.030 \mathrm{~mm}$ in length and $0.070 \mathrm{~mm}$ in breadth. Rostellum armed with 28-30 hooks, arranged in two semicircle unequal length i.e. short and long. Long hooks measures $0.083 \mathrm{~mm}$ in length and $0.009 \mathrm{~mm}$ in breadth, while short hooks measures $0.071 \mathrm{~mm}$ in length and $0.009 \mathrm{~mm}$ in breadth. Neck is absent. Mature proglottids 6-7 times broader than long and measures $0.337 \mathrm{~mm}$ in length and $1.618 \mathrm{~mm}$ in breadth. Testes are small, oval, 175-200 in number, scattered throughout the segment and measures $0.024 \mathrm{~mm}$ in length and $0.019 \mathrm{~mm}$ in breadth. Cirrus pouch is oval, preovarian and measures $0.065 \mathrm{~mm}$ in length and $0.021 \mathrm{~mm}$ in breadth. Cirrus short, thin, present within the cirrus pouch and measures $0.046 \mathrm{~mm}$ in length and $0.009 \mathrm{~mm}$ in breadth. Vas deferens short, thin, straight tube and measures $0.019 \mathrm{~mm}$ in length and $0.009 \mathrm{~mm}$ in breadth. Vagina and cirrus pouch open a common genital pore, which is small, oval and measures $0.012 \mathrm{~mm}$ in length and 0.09 $\mathrm{mm}$ in breadth. Vagina is thin tube, slightly curved, arises from the genital pore, runs posteriorly and forms receptaculum seminis and measures 0.065 $\mathrm{mm}$ in length and $0.009 \mathrm{~mm}$ in breadth. Receptaculum seminis is straight tube open into ootype and measures $0.021 \mathrm{~mm}$ in length and 0.014 $\mathrm{mm}$ in breadth, which is oval, medium in size, present between the ovarian lobes and measures $0.053 \mathrm{~mm}$ in diameter. From the ootype ovarian lobes start. Ovary is large, distinctly bilobed, transversely placed at posterior margin of the proglottids and measures $0.497 \mathrm{~mm}$ in length and $0.055 \mathrm{~mm}$ in breadth. Vitellaria granular, on each lateral side from anterior to posterior margin of the proglottids. Uterus saccular, filled with eggs and measures $0.145 \mathrm{~mm}$ in length and $0.342 \mathrm{~mm}$ in breadth. Eggs are elongated, tapering at both ends and measures $0.040 \mathrm{~mm}$ in length and $0.015 \mathrm{~mm}$ in breadth. Uterine pore rounded, to words anterior region of the proglottids and measures $0.028 \mathrm{~mm}$ in diameter.

\section{Host-Mastacembelus armatus}

Habitat-Intestine

Locality-Latur, M.S.India

The Senga satarensis Bhure et al.,(2011) comes closer to known species of the genus Senga Dollfus, 1934 in general topography of organ but differs due to taxonomic characters as scolex pear shaped, tapering anteriorly and broad posteriorly, rostellum medium, rounded, bearing 28-30 rostellar hooks, neck absent, mature proglottids six to seven times broader than long, testes 175-200 in numbers, scattered throughout the segment, cirrus pouch oval, ovary distinctly bilobed, vagina thin, runs posteriorly, genital pores oval in shape, vitellaria granular, uterus saccular and egg elongated. 


\section{Senga madhavae Bhure et al., 2010:}

The present worm consisting scolex, immature, mature and gravid proglottids. Scolex triangular, tapering anteriorly and broad posteriorly and measures $0.910 \mathrm{~mm} \times 0.519 \mathrm{~mm}$ in length and breadth. Scolex having pair of bothria, which extends from the anterior end to posterior end of the scolex and measures $0.958 \mathrm{~mm} \times 0.106 \mathrm{~mm}$ in length and breadth. Anterior end of scolex terminates in a rostellum, which is rounded in shape and measures $0.101 \mathrm{~mm} \times 0.247 \mathrm{~mm}$ in length and breadth. Rosetellum armed with 40-44 hooks, which are arranged in two semicircle unequal length i.e. short and long .Long hooks measures $0.108 \mathrm{~mm} \times 0.010 \mathrm{~mm}$ in length and breadth, while short hooks measures $0.85 \mathrm{~mm} \times 0.006 \mathrm{~mm}$ in length and breadth. Neck is absent. Mature proglottids 5-6 times broader than long and measures $0.271 \mathrm{~mm} \times 2.199 \mathrm{~mm}$ in length and breadth. Testes small, oval, 200-220 in number, scattered throughout the segment and measures $0.021 \mathrm{~mm} \times 0.031 \mathrm{~mm}$ in length and breadth. Cirrus pouch oval, pre-ovarian, situated in the centre of the segment and measures $0.058 \mathrm{~mm} \times 0.024 \mathrm{~mm}$ in length and breadth. Cirrus short, thin, present within the cirrus pouch and measures $0.046 \mathrm{~mm} \times$ $0.009 \mathrm{~mm}$ in length and breadth. Vas deferens is short, thin, straight tube and measures $0.019 \mathrm{~mm} \times$ $0.007 \mathrm{~mm}$ in length and breadth. Vagina and cirrus pouch open a common pore known as genital pore, which is small in size, oval in shape and measures $0.012 \mathrm{~mm} \times 0.09 \mathrm{~mm}$ in length and breadth. Vagina is a thin tube, slightly curved, arises from the genital pore, runs posteriorly and forms receptaculum seminis and measures $0.094 \mathrm{~mm}$ $\times 0.009 \mathrm{~mm}$ in length and breadth. Receptaculum seminis is straight tube open into ootype and measures $0.029 \mathrm{~mm} \times 0.009 \mathrm{~mm}$ in length and breadth. Ootype oval, medium in size and measures $0.024 \mathrm{~mm}$ in diameter; from the ootype ovarian lobes start and form the ovary, which is large, distinctly bilobed, dumb-bell shaped and measures $0.992 \mathrm{~mm} \times 0.116 \mathrm{~mm}$ in length and breadth Vitellaria granular, on each lateral side from anterior to posterior margin of the proglottids. Uterus saccular, filled with eggs and measures $0.065 \mathrm{~mm} \times 0.538 \mathrm{~mm}$ in length and breadth. Eggs elongated, tapering at both ends and measures $0.043 \mathrm{~mm} \times 0.012 \mathrm{~mm}$ in length and breadth.
Uterine pore is rounded, to words anterior region of the proglottids and measures $0.024 \mathrm{~mm}$ in diameter. Host-Mastacembelus armatus Habitat-Intestine Locality-Osmanabad, M.S.India

The Senga madhavae Bhure et al.,2010 comes closer to known species of this genus in general topography of organ but differs due to scolex triangular, tapering anteriorly and broad posteriorly, rostellum medium, rounded, bearing 40-44 rostellar hooks, neck absent, mature proglottids five to six times broader than long, testes 200-220 in numbers, scattered throughout the segment, cirrus pouch oval, ovary distinctly bilobed, dumb-bell shaped vagina thin, runs posteriorly, genital pores oval in shape, vitellaria granular, uterus saccular and egg elongated.

\section{Senga mangalbai Bhure et al., 2011 :}

All the cestodes are long, consisting of scolex, immature, mature and gravid proglottids. Scolex conical, tapering at the apex and broad at the base, distinctly marked off from the strobila and measures $2.038 \mathrm{~mm}$ in length and $0.878 \mathrm{~mm}$ in width. Scolex is having two fleshy bothria, which extends from the anterior end to posterior end of scolex and measures $1.662 \mathrm{~mm}$ in length and 0.349 $\mathrm{mm}$ in width. Anterior end of scolex bears rostellum, which is armed, oval to rounded and measures $0.116 \mathrm{~mm}$ in length and $0.266 \mathrm{~mm}$ in width. Rostellum armed with 38-42 hooks, which are of two types i.e. long and short. Long hooks measure $0.093 \mathrm{~mm}$ in length and $0.010 \mathrm{~mm}$ in width while short hooks measures $0.064 \mathrm{~mm}$ in length and $0.008 \mathrm{~mm}$ in width respectively. Neck absent. Mature proglottids are 2-3 times broader than long and measures $0.449 \mathrm{~mm}$ in length and $1.084 \mathrm{~mm}$ in width. Testes are oval to rounded, 7080 in numbers, scattered lateral side of the segment on either side of ovary and cirrus pouch and measures $0.024 \mathrm{~mm}$ in length and $0.019 \mathrm{~mm}$ in width. Cirrus pouch small, oval, transversely placed, pre - ovarian and measures $0.080 \mathrm{~mm}$ in length and $0.041 \mathrm{~mm}$ in width. Cirrus is thin, straight within the cirrus pouch and measures 0.084 $\mathrm{mm}$ in length and $0.009 \mathrm{~mm}$ in width. Vas deferens short, thin tube and measures $0.024 \mathrm{~mm}$ in length and $0.012 \mathrm{~mm}$ in width. Vagina and cirrus pouch open at the distal end by a common genital pores, which is small, oval and measures $0.019 \mathrm{~mm}$ in length and $0.012 \mathrm{~mm}$ in width. Vagina arises from the gonopore, which is thin tube, runs towards 
posterior side, forms receptaculum seminis and measures $0.050 \mathrm{~mm}$ in length and $0.007 \mathrm{~mm}$ in width. Receptaculum seminis is thin, short tube, it opens into ootype and measures $0.031 \mathrm{~mm}$ in length and $0.012 \mathrm{~mm}$ in width. Ootype is small, oval to round in shape and measures $0.029 \mathrm{~mm}$ in diameter. From Ootype, ovarian lobes start. Ovary large, distinctly bilobed, each lobe like a nut shaped, situated near the posterior margin of the segment and measures $0.439 \mathrm{~mm}$ in length and $0.077 \mathrm{~mm}$ in width. Uterus saccular, filled with numerous egg and measures $0.196 \mathrm{~mm}$ in length and $0.415 \mathrm{~mm}$ in width. Eggs are oval, nonoperculated and measures $0.034 \mathrm{~mm}$ in length and $0.016 \mathrm{~mm}$ in width. The uterine port is rounded, touching to the anterior side of the segment and measures $0.034 \mathrm{~mm}$ in diameter. Vitellaria are granular, arranged in 2-3 rows, on each lateral side from anterior to posterior margin of proglottids.

Host-Mastacembelus armatus Habitat-Intestine Locality-Nanded, M.S.India

The Senga mangalbai Bhure et.al.,2011 comes closer to all the known species of this genus in general topography of organ but differs due to shape of scolex (conical), hooks 38-42 in numbers, absence of neck, size of mature proglottids( 2-3 times broader than long), number and arrangement of testes (70-80 in numbers and scattered lateral side of the proglottids on either side of ovary and cirrus pouch), length of vagina $\{0.050 \mathrm{~mm}\}$, shape of ovary (distinctly bilobed, each lobe nut shaped) and vitellaria granular.

\section{Senga microrostellata Bhure et al., 2014:}

Cestodes are long, consisting of scolex, immature, mature and gravid proglottids. Scolex triangular, tapering at apex and broad at the base, distinctly marked off from strobila and measures $1.218 \mathrm{~mm}$ in length and $0.686 \mathrm{~mm}$ in width. Scolex is having two sessile bothria, which extends from anterior end to posterior end of scolex and measures 1.072 $\mathrm{mm}$ in length and $0.266 \mathrm{~mm}$ in width. Anterior end of scolex bears rostellum, which is armed, oval in shape and measures $0.109 \mathrm{~mm}$ in length and 0.206 $\mathrm{mm}$ in width. Rostellum armed with 18-20 hooks, arranged in a circle, which are of two types i.e. long and short. Long hooks measure $0.097 \mathrm{~mm}$ in length and $0.009 \mathrm{~mm}$ in width, while short hooks measures $0.085 \mathrm{~mm}$ in length and $0.007 \mathrm{~mm}$ in width respectively. Neck absent. Mature proglottids are 8-9 times broader than long and measures 0.211 $\mathrm{mm}$ in length and $3.407 \mathrm{~mm}$ in width. Testes small, oval to rounded in shape, 250-300 in numbers, scattered lateral side of the segment on either side of ovary and cirrus pouch and measures $0.016 \mathrm{~mm}$ in length and $0.019 \mathrm{~mm}$ in width. Cirrus pouch small, elongated, transversely placed, pre-ovarian and measures $0.060 \mathrm{~mm}$ in length and $0.029 \mathrm{~mm}$ in width. Cirrus thin, short, straight, within the cirrus pouch and measures $0.038 \mathrm{~mm}$ in length and 0.012 $\mathrm{mm}$ in width. Vas deferens short, thin tube and measures $0.016 \mathrm{~mm}$ in length and $0.009 \mathrm{~mm}$ in width. Vagina and cirrus pouch open at the distal end by a common genital pore, which is small, oval and measures $0.016 \mathrm{~mm}$ in length and $0.012 \mathrm{~mm}$ in width. Vagina arises from gonopore, which is thin tube, runs towards posterior side, forms receptaculum seminis and measures $0.055 \mathrm{~mm}$ in length and $0.012 \mathrm{~mm}$ in width. Receptaculum seminis is thin, short tube, opens into ootype and measures $0.021 \mathrm{~mm}$ in length and $0.012 \mathrm{~mm}$ in width. Ootype is small, oval to rounded in shape and measures $0.019 \mathrm{~mm}$ in diameter. From ootype ovarian lobes start. Ovary large, distinctly bilobed, dumb-bell shaped, situated near the posterior margin of segment and measures $0.538 \mathrm{~mm}$ in length and $0.041 \mathrm{~mm}$ in width.Uterus is saccular, filled with numerous egg and measures $0.050 \mathrm{~mm}$ in length and $0.40 \mathrm{~mm}$ in width. Eggs oval, nonoperculated and measures $0.044 \mathrm{~mm}$ in length and $0.019 \mathrm{~mm}$ in width. Uterine pore rounded, touching to anterior side of segment and measures $0.032 \mathrm{~mm}$ in diameter. Vitellaria are follicular, arranged in a line, on each lateral side from anterior to posterior margin of proglottids.

\section{Host-Mastacembelus armatus Habitat-Intestine} Locality-Parbhani, M.S.India

The Senga microrostellata Bhure et.al.,2014 comes closer to all known species of this genus in general topography of organ but differs due to scolex triangular, tapering at apex and broad at the base, bothria sessile, rostellum armed with 18-20 hooks which is single circled, absence of neck, mature proglottids 8-9 times broader than long, testes 250300 in numbers, scattered lateral side of the proglottids, cirrus pouch elongated, vagina runs posteriorly, ovary dumb-bell shaped, uterus sacular filled with non-operculated eggs and vitellaria follicular. 
Reports on cestode genus Senga
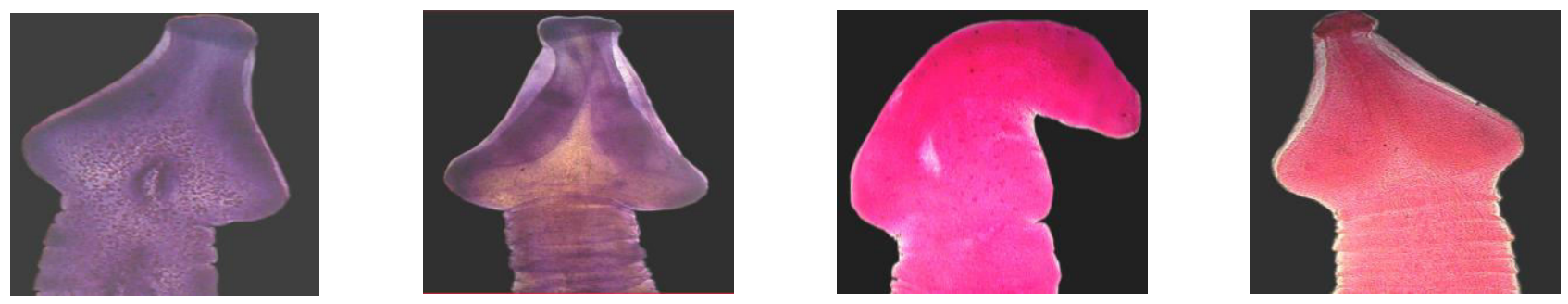

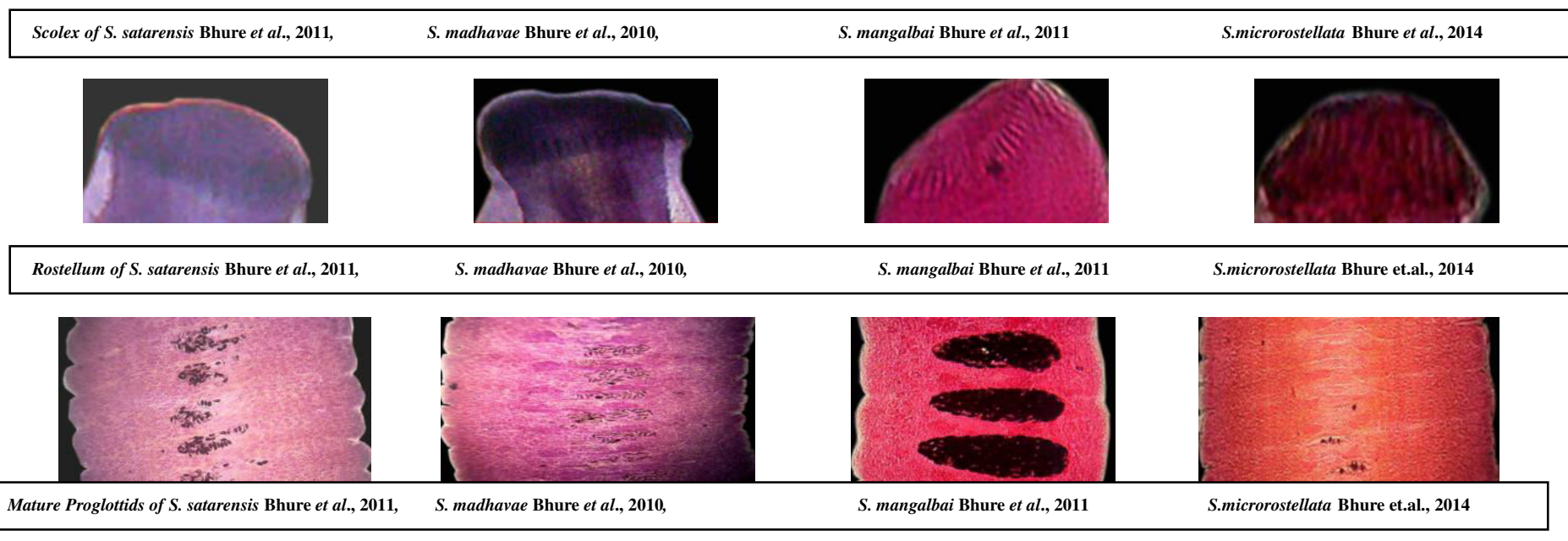

Figure 1- Micro-photograph of S. satarensis Bhure et al., 2011,, S. madhavae Bhure et al., 2010, S. mangalbai Bhure et al., 2011 and S.microrostellata Bhure et al. 2014
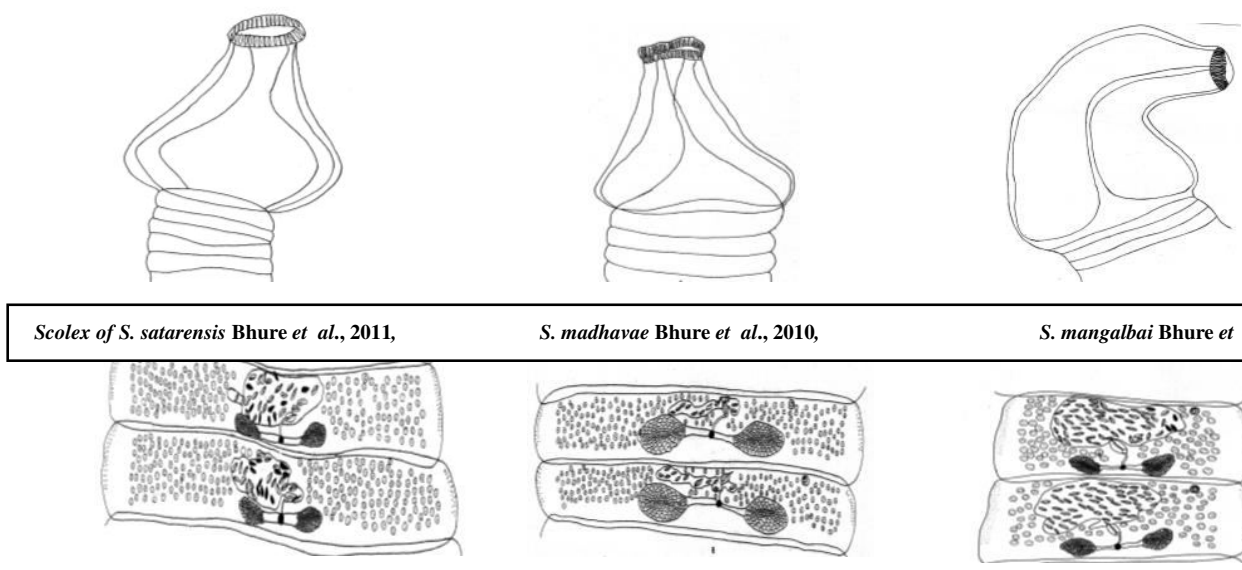

Mature Proglottids of S. satarensis Bhure et al., 2011, S. madhavae Bhure et al., 2010,
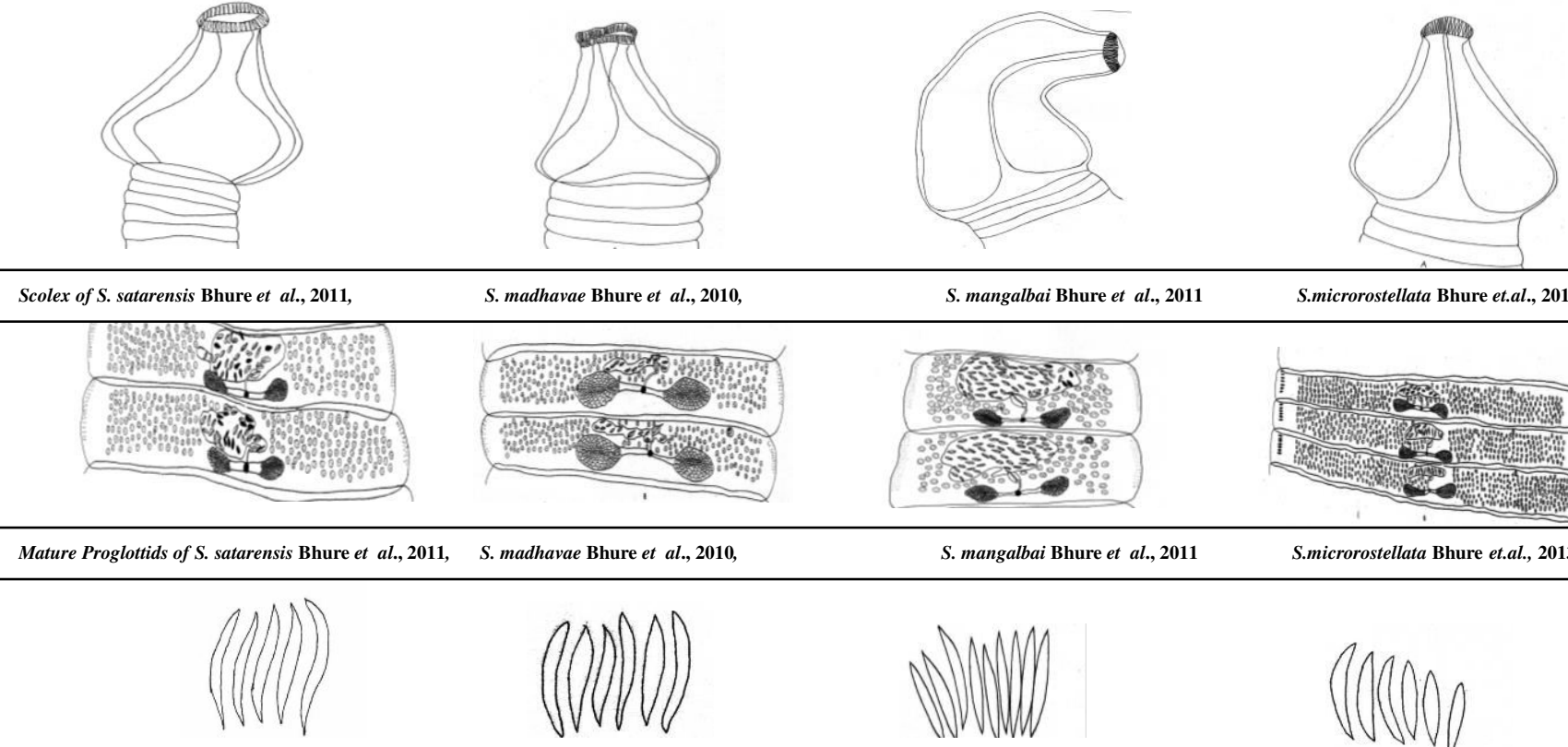

Hooks of S. satarensis Bhure et al., 2011,

S. madhavae Bhure et al., 2010,

S. mangalbai Bhure et al., 2011

S.microrostellata Bhure et.al., 2014
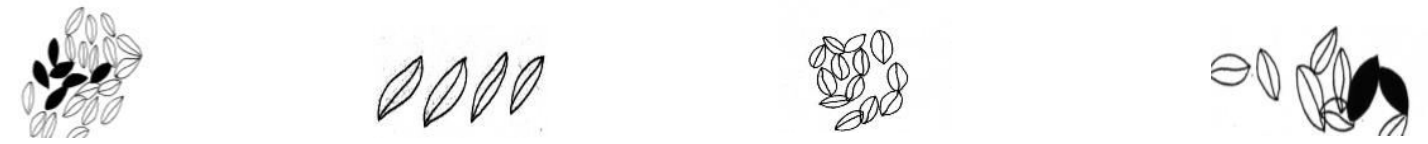

Eggs of S. satarensis Bhure et al., 2011,

S. madhavae Bhure et al., 2010,

S. mangalbai Bhure et al., 2011

S.microrostellata Bhure et.al., 2014

$0.125 \mathrm{~mm}$

Figure 2- Camera lucida diagram of S. satarensis Bhure et al., 2011, S. madhavae Bhure et al., 2010, S. mangalbai Bhure et al ., 2011 and S.microrostellata Bhure et.al., 2014

Environment Conservation Journal 


\section{Acknowledgements}

DBB is indebted to SERB, New Delhi for sanctioning the Fast Track Research Project No. SR/FT/LS-19/2010 Dt. $2^{\text {nd }}$ May, 2012. The authors are indebted to Dr. N.V. Kalyankar, Principal, Yeshwant Mahavidyalaya Nanded for their kind help, inspiration and providing necessary laboratory facilities.

\section{References}

Bhure, D. B., Padwal, N. D. and Jadhav, B. V. 2007. A new tapeworm Senga jadhavii N.Sp.(Cestoda: Pseudophyllidea) from Mastacembelus armatus at Aurangabad. Proc. Zool. Soc. of India, 6(2): 45-52.

Bhure, D. B., Nanware, S. S., Pathan, D. M., and Dhondge, R. M. 2010. Morpho-taxonomic observation of new Pseudophyllidean tapeworm Senga Dollfus, 1934 from Mastacembelus armatus. The Asian Journal of Animal Science 5 (2): 147-152.

Bhure, Dhanraj Balbhim and Nanware, Sanjay Shamrao 2011. Systematic observation of new pseudophyllidean tapeworm Senga from Mastacembelus armatus. International Multidisciplinary Research Journal. 1(10): 25-28.

Bhure, D. B. Nanware, S. S. and Deshmukh V.S. 2014 Biosystemic studies on cestode genus Senga (Dollfus,1934) (Ptychobothridae, Luhe,1902) from Mastacembelus armatus with description of a new species. Proceeding of modern Parasitology Narendra Publishing house New Delhi Vol. I chapter 26 pp 233-244.

Bhure, Dhanraj Balbhim and Nanware, Sanjay Shamrao 2011. Studies on cestode genus Senga (Dollfus, 1934) (Ptychobothridae, Luhe,1902) from Mastacembelus armatus with description of a new species. Proceeding of the Zoological Society of India (Special IssueParasitology). 1: 91-98.

Dollfus, R. Ph. 1934. Sur uncestode pseudophyllidae parasite de poiss on ornament. Bull.Sac. Zool. France 69: 476-490

Fernando, C. H. and Furtado, J. I. 1964. Helminth parasites of some Malayan freshwater fishes. Bulletin of the National Museum, State of Singapore 32: 45-71.

Fernando, C. H. and Furtado, J. I. 1963. A study of Some helminth parasites of freshwater fishes in Ceylon Zeit. Parasitenkunde 23: 141-163

Fernando, C. H. and Furtado, J. I. 1964. Helminth parasites of Some Malayan freshwater fishes. Bulletin of the National Museum of states of Singapore, 32: 45-71.
Hiware, C.J., Jadhav, B. V. and Mohekar, A. D. 2003. Applied Parasitology A practical manual Mangal Deep Publ. Jaipur.243 pp

Jadhav, B. V. and Shinde, G. B.1980. On a new cestode Senga aurangabadensis n.sp. from the fish Mastacembalus armatus. Bioresearch, 43(2): 25-27.

Jadhav, B. V., Ghavane A.B.and Jadhav A.P. 1991. On a new Pseudophylidean cestode from Mastacembelus armatus at Daryapur (M.S.) India. Rivista Di Parasit. 8( 1):19-22

Jadhav, B. V., Deshmukh, S. B. and Gavhane, A. B. 1991. A new tapewarm Senga gachuae n.sp. from the fish Channa gachua at Aurangbad. India. J. Inv.Zool and Aqu Biol. 3 (1): $39-41$

Jadhav, B. V. 2005. Cestoda of the genus Senga (Cestoda Pseudophyllidea) from freshwater fishes in Maharashtra, India A survey of species. Riv Para. 22\{ LXVIL ;2\}: 93101

Johri, G. N. 1956. A New cestode Segna lucknowensis from Mastacembalus armatus (Lecep.).Supplement to Current Science 15: 193-195.

Kadam, S.S., Jadhav, B.V. and Shinde, G. B.1981. On a new cestode Senga paithanensis n.sp. (Cestoda; Ptychobothriidae) from Mastacemballus armatus. Bioresearch 5 (1): 95-96

Khalil, L.F, Jones, A. and Bray, R.A, 1994. Keys to the cestodes parasites of vertebrates. CAB International Pub. U.K. pp.1-751.

Majid, M. A. and Shinde G. B. 1984. Two new species of the genus Senga Dollfus, 1934 (Cestoda-Pseudophyllidea) from fresh water fishes at Jagannathpuri, Orisa. India. $J$. of Para. (1): 169-172

Pande, P. N., Mittal, Neetu and Singh, S. R. 2000. On a new cestode of the genus Senga, Dollfus, 1934 from the intestine of freshwater fish Mastacembalus armatus (Lacep) from Kanpur, U. P.Indian. Jr. Hel. (N. S.) (17): 58

Patil, D. N. and Jadhav, B.V. 2003. On a new species of the Segna Dollfus 1934 Cestoda- Ptychobothridoe Luhe, 1902 as $S$. tappi n.sp. from the Shirpur Dist. Dhule (M.S.) India. J. Comp. Tox. Physiol (1): 68-72.

Ramadevi, P. and Rao, K. H. 1966. Pleurocercoid of Senga (Pseudophyllidea: Ptychobothriidae) from the freshwater fish, Panchax panchax (Haml and Buch). Current Sci. 35 (24): 626-627.

Ramadevi, P. 1973. On Senga visakhapatnamensis n.sp. (Cestoda - Pseudophyllidea) from the intestine of the freshwater fish Ophiocephalus puncatus Bloch. Rivista Di. Para 34(-4): 281-286. 
Shinde G. B. 1972. Studies on Indian Cestode rediscription of Senga besnardi Dollfus, 1934.Mar. Uni. J. of Sci. (2): 3940

Schmidt, Gerald D. 1934. Handbook of Tapeworm Identification. CRC Press, Inc. Boca Raton, Florida. pp 1675.

Srivastav, A. K., Khare, R. K., Khare, Jitendra, Sahu, V. K., and Singh, A. R. 2007. A new species of genus Senga Dollfus (1934) from Punctius ticto at Jhansi (U.P.). Nat. Jr. of Life Sci. 4(3): 129-132.

Tat, M. B. and Jadhav, B.V.1997. Senga mohekarae n.sp (Cestoda-Ptychobothridae) from Mastacembalus armatus. Riv. Di. Para. \{XVII (LVIII) N-2\}: 203-296
Tseng's 1933. Study on same Cestode from fishes. J. of Sci. National Univ. Shantuma. Tsingtao, China (2): 1-21.

Wardle, R.A., Mcleod, J.A. and Radinovsky 1974. Advances in the Zoology of tapeworm 1950-1970, University of Minnesotar Press, Minneapolis 1-780.

Woodland, W. N. F. 1934. On a new Bothriocephalus and a new genus Bothrioceohallidae from Indian freshwater fishes. Parasit. (16):441-451.

Yamaguti, S. 1959. Systema Helminthum. II.The Cestodes of Vertebrates. Intescience Publ., N.Y., pp 860. 